\title{
SKILL DEVELOPMENT TRAINING AS AN INFLUENCER OF CAPACITY BUILDING AND ECONOMIC EMPOWERMENT OF WOMEN SELF HELP GROUPS - A STUDY CONDUCTED AT SHIMOGA DISTRICT
}

*Krupa, V. D

\begin{abstract}
:
Presently the GOI is giving more emphasis on women empowerment and sustainable development of rural area. For converting the idle society into self-sustainable society there is a need for economic empowerment of women. SHG is the key main means for the empowerment of women, GOI has under taken many programmes and one among them is SGSY. SGSY programme not only mobilize micro finance and provide micro credit to the needed members but also provides self-employment training, awareness programme, promotes the leadership qualities and confidential life to its members. The main purpose of this programme is to provide capacity building programme for empowerment of women through SHGs. However, this study is conducted to know whether this programmes has impacted on the economic condition in the Shimoga region. The study is purely based on primary data, the result showing that economic condition of the poor women has improved after joining the SGSY programme.
\end{abstract}

Key Words: Capacity building, SGSY - Swarnajayanti Gram Swarozgar Yojana, SHG -Self Help Group

\section{Introduction}

In spite of five years planning of GOI (Government of India), rural poverty in India still continues to be worrisome. While the GOI has under taken various anti-poverty programmes to strengthen it such as IRDP (Integrated Rural Development Programme), TRYSEM (Training of Rural Youth for SelfEmployment), DWCRA(Development of Women and children in rural areas ) etc, this has resulted in the reduction of poverty levels in percentage terms from $54.9 \%$ of India's population in $1973-74$ to $36 \%$ in $1993-94$ to $26.1 \%$ in1999-2000 and in 2011 the GOI stated that $21.9 \%$ of its population is below poverty line. However the number of rural poor has not reduced considerably.

To redress the situation at a faster pace Selfemployment is one of the significant steps. Hence, in April 1999 GOI launched an integrated self-employment programme i.e., Swarnajayanti Gram Swarozgar Yojana

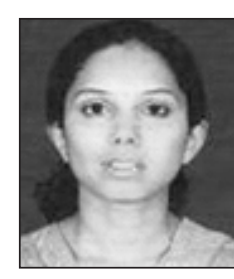


(SGSY). Through this programme Government attempts to support capacity building and create provisions of income generation of rural poor through bank credit and subsidy. This programme aims at establishing large number of micro enterprises through SHGs in the rural areas to build upon the potential of rural poor with the support of NGOs, SHPIs (Self Help Promoting Institution), Commercial Banks etc,. Now SGSY programmes is redesigned as National Rural Health Mission (NRHM).

This is a holistic program for Self Help Groups (SHGs) and their capacity building, providing skill development training, selection of key activities and planning of activity clusters, infrastructure build up, technology and marketing support. SGSY is funded by the central and the states in the ratio of 75:25.

The objective of the SGSY is to bring the assisted poor families (Swarozgaris) above the Poverty Line by providing them incomegenerating assets through a mix of Bank Credit and Governmental Subsidy. The programme aims at establishing a large number of micro enterprises in rural areas based on the ability of the poor and potential of each area.

\section{Target Group}

Families below the Poverty Line (BPL) in rural areas are the target group of the SGSY. Within the target group, special safeguards have been provided to vulnerable sections, by way of reserving $50 \%$ benefits for SCs/STs, $40 \%$ for women and 3\% for disabled persons.

\begin{tabular}{|c|c|c|c|}
\hline \multirow[b]{2}{*}{$\begin{array}{l}\text { Sl. } \\
\text { No }\end{array}$} & \multirow[b]{2}{*}{ Particulars } & \multicolumn{2}{|c|}{ Achievements } \\
\hline & & $\begin{array}{c}\text { Physical } \\
\text { (No. in lakh) }\end{array}$ & $\begin{array}{r}\text { Financial } \\
\text { (Rs. crore) }\end{array}$ \\
\hline I & Total number of SHGs saving linked with banks & 76.97 & 11059.86 \\
\hline a) & Out of total SHGs - exclusive Women SHGs & 66.52 & 9264.33 \\
\hline b) & Out of total SHGs- under NRLM/SGSY & 30.52 & 4424.03 \\
\hline II & Total number of SHGs credit linked during 2014-15 & & \\
\hline a) & Out of total SHGs - exclusive Women SHGs & 14.48 & 24419.75 \\
\hline b) & Out of total SHGs - under NRLM/SGSY & 6.43 & 9487.69 \\
\hline III & $\begin{array}{l}\text { Total number of SHGs having loans outstanding as } \\
\text { on } 31 \text { March } 2015\end{array}$ & 44.68 & 51545.46 \\
\hline a) & Out of total SHGs - exclusive Women SHGs & 38.58 & 45901.95 \\
\hline b) & Out of total SHGs - under NRLM/SGSY & 18.46 & 19752.74 \\
\hline
\end{tabular}

Source: NABARD Report, 2014-15

\section{Review of Literature}

Ajay Kumar Deka, Padmalochan Hazarika (January 2013), Generation of Income of Rural Poor through Swarnajayanti Gram Swarozgar Yojana (SGSY) -A Study Relating to Kamrup District (Rural) of Assam, this study found that after joining SGSY the SHG members income significantly increased. 
Hemalatha, A. V (November 2012), Skill development of Women micro-entrepreneurs A study among Self Help Group members in Kerala, this study made the significance of group approach through micro finance system which helped SHG members to venture into enterprises with skill and confidence are examined and the present study made an attempt to assess the skill development of rural women through the formation of Self Help Groups in different parts of Kerala.

Bhumika Bor (Sep. 2014), Impact of Swarnajayanti Gram Swarozgar Yojana (Sgsy) On Poverty Alleviation in Golaghat District, Assam, this paper highlights the impacts of SGSY programmes on poverty alleviation of the rural poor in the Golaghat District. The main objective of this paper is to identify the impact of SGSY programme and constraints of the beneficiaries in increasing their income level.

Shylendra,H. S and Kishore Bhirdikar, Good governance and poverty alleviation programmes: A critical analysis of Swarnjayanti Swarozgar Yojana (SGSY), the paper attempts to examine the flagship poverty alleviation scheme SGSY against the background of emerging policies aimed at good governance and reveals that SGSY is beset with problems like faulty selection, improper identification of viable schemes, sidelining of capacity building and above all lack of integration among different agencies involved in implementation of the scheme.

UpenKonch (2016), Self-help groups (SHGs) as a potential tool for economic empowerment of women in selected districts of Assam: A comparative experience, the present study found that the achievement of SHGs movement in economic empowerment of women was not satisfactory in the selected districts of Assam.
Therefore the study suggested that intensive efforts and attention should be initiated by the government of Assam in order to realize the objectives of SHGs movement in the state.

Mallikarjuna,T(March 2016), SHG Bank Linkage Programme as a vaccine for Women Empowerment: A Sociological review in Chittoor District, he states that majority of groups are linked with the help and support of SHGs for financial services and specialized training, and these groups have a greater ability to make a positive impact on women empowerment. But in the study area, it is difficult to believe that a minimalist SHGs programme would have a sustainable impact on the empowerment of women. So, study has suggested that there is a need to make many changes for truly empowerment of women.

Kishore Mathew Arnold (March 2016), Women Empowerment Through Swarnajayanthi Gram Swarozgar Yojana, the present study has analyzed the development of rural women entrepreneurs through Swarnajayanthi Gram Swarozgar Yojana (SGSY) scheme, the progress of the members of the SHGs and to find out how far SHGs are successful in creating women entrepreneurs thereby empowering poor women.

\section{Conceptual framework of key terms}

Skill Development Training: The skill development training (EDP) programme in general will help the members of the SHGs to become financially self-reliant, by helping them to commence the suitable income generating activities and managing them successfully and also to get motivated and to facilitate in providing all the requirements.

Capacity Building: SGSY/NRLM ensures that the poor are provided with the requisite skills 
for managing their institutions, linking up with markets, managing their existing livelihoods, enhancing their credit absorption capacity and credit worthiness.

Economic Empowerment: Economic empowerment is the ability to access, own and control resources. It can be measured in a variety of ways, using outcome indicators such as income generation, ownership of assets and land, expenditure patterns, degree of participation in paid employment, division of domestic labour and control over financial decision-making.

\section{Objectives of the Study}

The main purpose of this study is to examine the impact of SGSY Skill Development Training on capacity building and Economic Empowerment of women Self-Help Groups in the study area.

\section{Research Methodology}

\subsection{Type of research}

This study is empirical in nature, conducted to know the impact of skill development training on the rural employment and development of women SHG members.

\subsection{Scope of the Study}

The study is conducted to know about the impact of SGSY skill development activities on the economic empowerment of the rural women SHG members. The geographical area for this study is restricted only for Shimoga district (the study has covered few taluks i.e., Thirthahalli, Hosanagar, Sagara)

\subsection{Sample Design}

$>$ Population: Women SHG members in rural area (Beneficiaries of capacity building Training)
$>$ Sampling Technique: The study has used convenient sampling method.

$>$ Sample Size: It is 150 respondents. Respondents are scattered over many villages, so structured questionnaire is used and interview is conducted only for the selected respondents of the study area.

\subsection{Hypothesis}

H0: SGSYskill development training has not become the aid for capacity building of SHG members.

H0: SGSY skill development training has not significantly improved the economic conditions of the beneficiaries.

Dependent Variable: Economic condition of beneficiaries

Independent Variable : SGSY skill development training

\subsection{Hypothesis Test}

The study has been tested by hypothesis and the study has used Microsoft Excel to do Chisquare test.

$$
\mathrm{X}^{2}=\sum_{i=1}^{n} \frac{\left(O_{i}-E_{i}\right)^{2}}{E_{i}},
$$

\subsection{Sources of Data}

The present study has used data both from primary and secondary sources. The primary data is gathered directly from concerned authorities and beneficiaries through structured interview and questionnaire.

The secondary data is collected from published sources such as various articles, reports, books, journals and periodicals. 
6. Analysis and Discussion

Table No: 6.1: Profile of respondents.

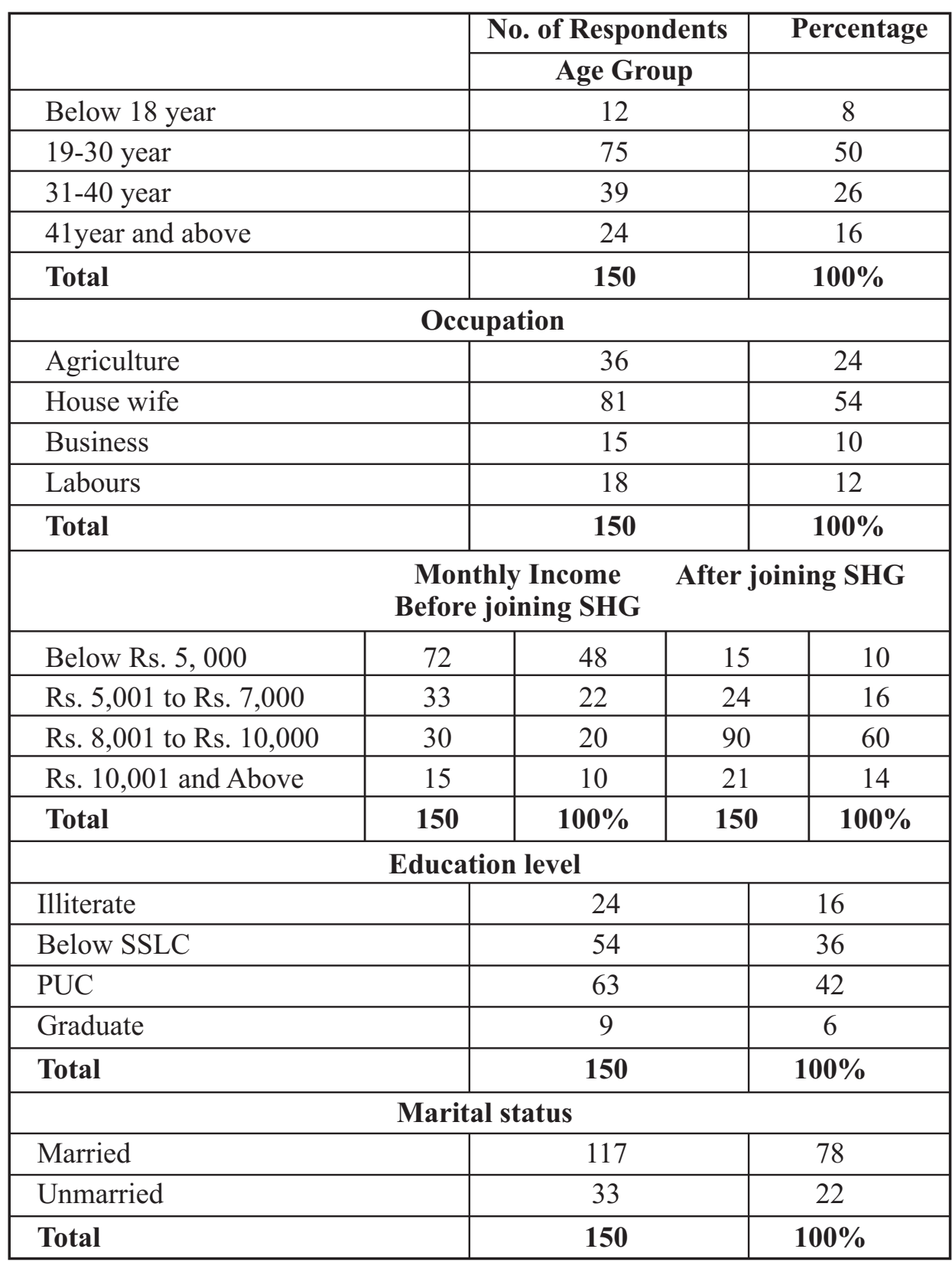

(Source: Primary data)

The above table indicates that, among 150 respondents, majority (50\%) of respondents are youngsters they belong to the age group of 19 to 30 years, only $8 \%$ of respondents are below 18 years old and rest of them belong to the age group of above 31 years, 54\% of respondents are housewives, $24 \%$ of them are agriculturist, $12 \%$ of them are labours and only $10 \%$ of them are engaged in business activities, before joining SHGs majority of respondents monthly income was less than Rs 5,000 and between Rs. 5,001 to Rs. 7,000. But after joining SHG majority of the 
respondents monthly income has been increased to Rs. 8,001 to Rs. 10,000. Only 16\% of respondents are illiterates and rest of them are educated, the majority $(78 \%)$ of the respondents are married and rest of them (22\%) of them are unmarried.

Table 6.2: The authority that gives skill development training under SGSY

\begin{tabular}{|l|c|c|}
\hline \multicolumn{1}{|c|}{ Institutions } & No. of respondents & Percentage \\
\hline NGO & 54 & 36 \\
\hline SHPIs & 30 & 20 \\
\hline $\begin{array}{l}\text { Banks (CB, RRB, district } \\
\text { training institutions) }\end{array}$ & 54 & 36 \\
\hline Others (PRIs etc,.) & 12 & 8 \\
\hline Total & $\mathbf{1 5 0}$ & $\mathbf{1 0 0 \%}$ \\
\hline
\end{tabular}

(Source: Primary data)

(NGOs- Non Government Organizations, SHPI - Self Help Promoting Institutions, CBs Commercial Banks, RRBs - Regional Rural Banks, PRIs - Panchayath Raj Institutions)

The above table shows that, in the study area NGOs, banks and SHPIs are actively engaged in providing skill development training for SHGs.

Table 6.3: Type of Income generating activity SHG members are engaged after skill development training

\begin{tabular}{|l|c|c|}
\hline Type of activity & No. of respondents & Percentage \\
\hline Consumer store & 15 & 10 \\
\hline Food processing unit & 54 & 36 \\
\hline Pot making & 9 & 6 \\
\hline Goat rearing & 12 & 8 \\
\hline Poultry, Diary farming & 9 & 6 \\
\hline Agarbathi making & 15 & 10 \\
\hline Bakery & 6 & 4 \\
\hline Tailoring unit & 21 & 14 \\
\hline Others & 9 & 6 \\
\hline Total & $\mathbf{1 5 0}$ & $\mathbf{1 0 0 \%}$ \\
\hline
\end{tabular}

(Source: Primary data)

From the above table, it is clear that all the SHG group members in the study area are engaged in income generating activates which they have learned from skill development training of SGSY. In the study area majority of the group members are engaged in food processing, tailoring, agarbathi making and consumer retail shop. 
Table 6.4: Impact of SGSY Skill Development Training on capacity building (Development of Entrepreneurial Skills) of respondents

H0: SGSYskill development training has not impacted on capacity building of SHG members.

\begin{tabular}{|l|c|c|c|c|l|l|}
\hline \multicolumn{1}{|c|}{ Factors } & SA & A & NA/NDA & DA & SDA & Total \\
\hline $\begin{array}{l}\text { Enhancement of capacity to } \\
\text { expand the existing business }\end{array}$ & 2 & 13 & 7 & 4 & - & 26 \\
\hline $\begin{array}{l}\text { Enhancement of capacityto start } \\
\text { a new business }\end{array}$ & 4 & 24 & 6 & 6 & - & 40 \\
\hline $\begin{array}{l}\text { Application of some new ideas } \\
\text { in business }\end{array}$ & 8 & 5 & 4 & 5 & 4 & 26 \\
\hline Communication skills improved & 3 & 4 & 5 & 1 & 2 & 15 \\
\hline Marketing skills improved & 2 & 26 & 4 & 1 & - & 33 \\
\hline Ability to manage the risk & - & 7 & 2 & 1 & - & 10 \\
\hline \multicolumn{1}{|c|}{ Total } & 19 & 79 & 28 & 18 & 6 & 150 \\
\hline
\end{tabular}

(Source: Primary data)

(SA- Strongly Agree, A- Agree, NA/NDA- Neither Agree nor Dis agree, DA- Dis Agree, SDAStrongly disagree

$$
\mathrm{X}^{2}=\sum_{i=1}^{n} \frac{\left(O_{i}-E_{i}\right)^{2}}{E_{i}}
$$

\begin{tabular}{|c|c|c|c|}
\hline $\begin{array}{c}\text { Table value @ 1\% level } \\
\text { of significance }\end{array}$ & $\begin{array}{c}\text { Table value @ 5\% } \\
\text { level of significance }\end{array}$ & $\begin{array}{c}\text { Computed } \\
\text { value }\end{array}$ & $\begin{array}{c}\text { Degree of freedom } \\
\text { (DF) }\end{array}$ \\
\hline 37.57 & 31.41 & 47.45 & 20 \\
\hline
\end{tabular}

As the calculated value is more than the table value at $1 \%$ and $5 \%$ level of significance, the null hypothesis is rejected and the alternative hypothesis is accepted. This shows that SGSY skill development training has positively impacted on capacity building of SHG members. 
Table 6.5: Impact of Skill Development Training on Economic empowerment of women SHG members

H0: SGSY skill development training has not significantly improved the economic condition of the beneficiaries.

\begin{tabular}{|l|c|c|c|c|c|}
\hline \multicolumn{1}{|c|}{ Factors } & SA & A & NA/NDA & DA & SDA \\
\hline Women empowerment & 15 & 110 & 20 & 3 & 2 \\
\hline Regular income & 12 & 128 & 5 & 5 & - \\
\hline $\begin{array}{l}\text { Liberty in decision making } \\
\text { with respect to expenditure } \\
\text { (investment) }\end{array}$ & 15 & 85 & 30 & 15 & 5 \\
\hline $\begin{array}{l}\text { Created awareness } \\
\text { about various institutional } \\
\text { support and Links with Banks } \\
\text { and formal financial } \\
\text { institutions }\end{array}$ & 10 & 30 & 80 & 20 & 10 \\
\hline $\begin{array}{l}\text { Enhanced savingsand } \\
\text { borrowed loans through } \\
\text { SHGs under SGSY } \\
\text { programme }\end{array}$ & 18 & 112 & 15 & 3 & 2 \\
\hline $\begin{array}{l}\text { Investment on income } \\
\text { generating activities }\end{array}$ & 20 & 115 & 5 & 10 & -- \\
\hline
\end{tabular}

(Source: Primary data)

(SA- Strongly Agree, A- Agree, NA/NDA- Neither Agree nor Dis agree, DA- Dis Agree, SDAStrongly disagree)

$$
\mathrm{X}^{2}=\sum_{i=1}^{n} \frac{\left(O_{i}-E_{i}\right)^{2}}{E_{i}}
$$

\begin{tabular}{|c|c|c|c|}
\hline $\begin{array}{c}\text { Table value @ 1\% level } \\
\text { of significance }\end{array}$ & $\begin{array}{c}\text { Table value @ 5\% } \\
\text { level of significance }\end{array}$ & $\begin{array}{c}\text { Computed } \\
\text { value }\end{array}$ & Degree of freedom \\
\hline 37.57 & 31.41 & 270.18 & 20 \\
\hline
\end{tabular}

As the calculated value is more than the table value at $1 \%$ and $5 \%$ level of significance, the null hypothesis is rejected and the alternative hypothesis is accepted. This shows that skill development training under SGSYis positively influencing the economic empowerment of women SHG members in the study area. 
Table 6.6: Problems of SGSY programme (reasons for failure of SGSY programme)

\begin{tabular}{|l|c|c|}
\hline Reasons for failure & No. of respondents & Percentage \\
\hline $\begin{array}{l}\text { Programme is not innovative for capacity } \\
\text { building of SHG members }\end{array}$ & 9 & 6.71 \\
\hline Delay in sanctioning the loan & 15 & 11.19 \\
\hline $\begin{array}{l}\text { Failed to target the real poor and } \\
\text { vulnerable sections }\end{array}$ & 12 & 8.95 \\
\hline $\begin{array}{l}\text { low survival rate of promoted micro } \\
\text { enterprises }\end{array}$ & 15 & 11.19 \\
\hline Inadequate loan amount sanctioned & 25 & 18.66 \\
\hline Limited period of repayment of loan & 13 & 7.463 \\
\hline Improper utilization of funds & 20 & 9.70 \\
\hline Lack of training manpower & 15 & 14.93 \\
\hline Insufficient basic infrastructure & $\mathbf{1 3 4}$ & 11.12 \\
\hline Total & $\mathbf{1 0 0}$ \\
\hline
\end{tabular}

(Source: Primary data)

Even though the SGSY has improved economic condition of SHG members, the programme couldn't reach the expected target. 134 respondents felt that the programme need to be improved and there are certain reasons for failure of the programme such as inadequate loan amount sanction, lack of training manpower, insufficient basic infrastructure, delay in sanctioning of loan under SGSY, low survival rate of promoted micro enterprises.

\section{Findings}

$\downarrow \quad$ Majority of the SHG group members in the study area belong to the age group of 19 to 30 and most of the SHG members are house wives in the study area.

$\downarrow$ Majority of the SHG members have received skill development training and they have engaged themselves in number of income generating activities.

$\downarrow$ NGOs, SHPIs, CBOs, district training institutions, RRBs are actively playing the role in the formation of SHGs and help in training and capacity building of facilitators used by DRDAs as well as SHGs.
As the 1st Null Hypothesis is rejected and alternative is accepted the following findings have been drawn:

$\downarrow$ With the support of SGSY skill development training majority of the SHG members have enhanced their capacity to expand their existing business.

$\downarrow$ The SGSY programmes encouraged the SHG members to start a new business with innovative sustainable ideas.

$\downarrow \quad$ The SGSY programmes also helped SHG members in application of some new ideas in business but some of the members have opined that this programme just provides 
training facility but it won't generate new ideas for business.

$\downarrow \quad$ Majority of the SHG members opined that, SGSY programmes have improved the marketing skill and communicating skills which are positively helping the SHG members to take productive investment decisions.

$\downarrow \quad$ Even SGSY training programme has also improved the risk management skill of SHG members

As the 2nd Null Hypothesis is rejected and alternative is accepted the following findings have been drawn:

$\downarrow \quad$ The alternative hypothesis shows that skill development training has positively impacted the economic empowerment of the SHG members.

$\downarrow \quad$ Majority of the SHG members agreed that skill development programmes are creating more employment for women.

$\downarrow$ Through the Skill development training SHGs members are getting regular income which has contributed to the economic independence of SHG members.

$\downarrow \quad$ Majority of the respondents agreed and strongly agreed that, skill development training also enhanced financial decision making ability of SHG members. Hence skill development training has become an aid for SHG members for their productive investment decision. But some of the respondents opine that skill development training restrict the SHG members for their investment decision because under SGSY programme all the SHG members are accountable for SHG group.

$\downarrow \quad$ Majority of the SHG members are linked and aware about various services of formal financial institutions before getting SGSY programme. But some of the SHG members agreed that they are aware of formal financial facilities through SGSY skill development training because their group (SHG) itself established under the support of SGSY.

$\downarrow$ Majority of the SHG members in the study area agreed that their savings and borrowings (loan) for the productive purpose have increased only from SGSY programme but very few of them opined that savings and borrowing loans through are a routine of every SGSY.

$\downarrow$ Majority of the SHG members agree that regular investment on income generating decisions were taken on the basis of the skill development activities which are under taken in SGSY programmes.

$\downarrow$ SGSY has failed to succeed because of these reasons, failed to take off the programmes innovatively; failed to mobilize the credit as per targets; failed to target the real poor and vulnerable sections; low survival rate of promoted micro-enterprises; realized additional income from the micro-enterprises is significantly less than anticipated.

$\downarrow$ Critical limitations of the program are

(a) Banks are not enthusiastically participating in the program due to mounting NPAS,

(b) Pilferage at different stages of implementation and

(c) The primary stakeholders are not participating whole heartedly in the program. 


\section{Suggestions}

$\downarrow$ The Panchayat Level Federations (PLF) provides a common platform for the SHGs to share their experiences and to voice their problems. Strengthening of PLFs is the key to achieve sustainability in the long run.

$\downarrow$ IT-based monitoring / evaluations mechanism are needed and grievance redressal mechanism should be established.

$\downarrow \quad$ The success of a Program like SGSY can be ensured only through peoples' participation. Therefore, states should federate the SHGs at various levels.

$\downarrow$ The Government should take necessary steps to provide all sorts of assistance in giving motivation training and leadership training to encourage the members to take up varied activities. Arrangements for marketing should also be widened so that easy marketing of produced articles is possible.

$\downarrow$ SHG members should try to engage in income generating activities and more skilled work so that higher amount of profit can be generated.

$\downarrow \quad$ Effective monitoring and follow-up system should be established at the appropriate level to ensure effective utilization of available resources and to strengthen group work.

$\downarrow$ Improved evaluation and monitoring for ensuring complete transparency and accountability in the implementation of SGSY can be ensured through social auditing of the scheme and third party evaluations. A national MIS for SGSY will also be put in place for better and continuous evaluation and monitoring. $\downarrow$ Greater Emphasis on Infrastructure and Marketing through the involvement of Private Sector and adoption of PPP model.

$\downarrow$ Continuation of capital subsidy at enhanced rates and the introduction of interest subsidy.

$\downarrow \quad$ Massive up-scaling of special projects for skill development and placement is needed.

$\downarrow \quad$ Setting up of one Rural Self Employment Training Institute (RSETI) in each district of the country for skill development training.

$\downarrow$ Special focus on training \& capacity building with dedicated staff/cells at the state, district and sub-district levels is required to ensure comprehensive training of SHGs and all other stakeholders.

$\downarrow$ It is proposed to have a dedicated professional institutional structure from Sub-district level up to national levels with suitable linkages with the existing network of DRDAs.

$\downarrow \quad$ The loan sanction process should be made easier and more repayment period should be given to swarazgaries to take the full advantage.

$\downarrow$ More information about the SGSY programme should be supplied in time and in the proper way.

$\downarrow \quad$ The quantum of loan amount should be increased with subsidy and less rate of interest

\section{Conclusion}

From above discussion it can be concluded that Shimoga district has achieved a commendable level of success in formation of SHGs in rural areas and it has also introduced SGSY 
programme in the district is a real programme for alleviation of poverty and unemployment in the rural areas. Most of the SHG members are from rural areas but micro-financing schemes have achieved in improving the economic conditions of the rural poor and protecting them from the controls of the village money lenders.Though SGSY helps in poverty alleviation some factors such as lack of basic facilities, lack of awareness, unnecessary delay of loan sanctioning and improper utilization of funds etc. To overcome those constrains awareness about skill development training among the beneficiaries, regular monitoring, minimization of the interest rate and motivation is utmost need to achieve the goal of such scheme.

\section{Reference:}

$\downarrow \quad$ Ajay Kumar Deka, PadmalochanHazarika (January 2013), Generation of Income of Rural Poor through Swarnajayanti Gram Swarozgar Yojana (Sgsy) -A Study Relating toKamrup District (Rural) of Assam, IJCAES Special issue on Basic, Applied \& Social Sciences, Volume III, pp. 44-47

$\downarrow$ Bhumika Bor (Sep. 2014), Impact of Swarnajayanti Gram Swarozgar Yojana (Sgsy) On Poverty Alleviation in Golaghat District, Assam, Journal Of Humanities And Social Science, Volume 19, Issue 9, Ver. V, PP 53-56

$\downarrow$ Ekatra, Evaluation of SGSY in selected blocks ofMadhya Pradesh, Sponsored byPlanning Commission, New Delhi, 2007

$\downarrow$ Goodwin, G \& Ritchie, A (2005), "Building Capacity for Retail Microfinance", Consultative Group for Alleviating Poverty.

$\downarrow \quad$ Hemalatha, A. V (November 2012), Skill development of Women micro entrepreneurs - A study among Self Help Group members in Kerala, Asia Pacific Journal of Marketing \& Management Review, Vol.1 No. 3, pp. 113-120.

$\downarrow$ Kishore Mathew Arnold (March 2016), Women Empowerment Through Swarnajayanthi Gram Swarozgar Yojana, Asian Academic Research Journal of Social Science \& Humanities, March 2016, Issue 3, Volume 3.

$\downarrow \quad$ Mallikarjuna, T (March 2016), SHG Bank Linkage Programme as a vaccine for Women Empowerment: A Sociological review in Chittoor District, International Journal of Advanced Research in Management and Social Sciences, March 2016, Vol. 5, No. 3, PP. 406-418

$\downarrow$ Manisha D. Bhingardive, Impact of skill development and human resource development ON SELF-help groups in select blocks of Thane district, Tactful Management Research Journal, pp. 101106

$\downarrow$ Mohan, B (2008) "Capacity Building: Needs and Challenges in India', Micro Save Bulletin, September.

$\downarrow \quad$ NABARD - micro fiancé report 2014-15.

$\downarrow$ Prabhakara, K.V, Training and Capacity Building of Self Help Groups - A Case Study from Karnataka.

$\downarrow$ Self-Help Group Capability Assessment 2007, Haryana community forestry project Forest Department Government of Haryana.

$\downarrow$ Shylendra H.S. and Kishore Bhirdikar, Good governance and poverty alleviation programmes: A critical analysis of Swarnjayanti Swarozgar Yojana (SGSY), 
$\downarrow \quad$ Subbalakshmi, A.V.V.S (December 2011), Role of self help groups in growth of rural women entrepreneurship through Microfinance, IJEMR, Vol 1 Issue 7.

$\downarrow$ Swain, B. K, Challenges for Capacity Building of SHG Members, Skoch Development Foundation report.

$\downarrow$ Tarique Zaryab, SHG: A Sustainable Livelihood To Promote Social Entrepreneurship (January, 2015), International Annual Conference Proceedings. $\downarrow$ United Nations Environment Programme (UNEP) discussion paper, Ways to Increase the Effectiveness of Capacity Building for Sustainable Development.

$\downarrow$ UpenKonch (2016), Self-help groups (SHGs) as a potential tool for economic empowerment of women in selected districts of Assam: A comparative experience, International Journal of Applied Research 2016, PP. 871-878 